\title{
DIVERSIFIKASI INVESTASI SAHAM: PERBANDINGAN RISIKO TOTAL PORTOFOLIO MELALUI DIVERSIFIKASI DOMESTIK DAN INTERNASIONAL
}

\author{
Tyas Auruma S. \\ I Made Sudana (imadesudana@yahoo.co.id) \\ Fakultas Ekonomi dan Bisnis Universitas Airlangga
}

\begin{abstract}
This study aims to obtain two empirical proofs, are about the difference of total portfolio risk between internationally diversification and domestically diversification, then, the influence of the number of shares in the portfolio toward the total risk of portfolio. The model analysis used in this study is the difference t test on average two independent sample groups and for effect estimation, using simple regression equation. There were 21 blue chips stocks( LQ45 Indonesia;DAX30 German;FTSE100 UK;DJA - USA) choosen randomly, and used as sampel for both of internationally diversification and domestically diversification within period beginning January until December 2011. The results show that there are a difference in the total risk of the portfolio which is generated through internationally diversification and domestically diversification. Total risk of portofolio internationally diversification is smaller than total risk of portfolio domestically diversification, and the number of shares in portfolio affect significant negative toward the total risk of portfolio.
\end{abstract}

Keyword: domestically diversification, internationally diversification, the number of shares, portfolio risk

\section{PENDAHULUAN}

Sejalan dengan perkembangan era globalisasi serta pertumbuhan ekonomi yang semakin pesat, investasi merupakan kegiatan yang tidak dapat dipisahkan dari kehidupan modern. Investasi dapat dilakukan pada jenis instrumen investasi dengan risiko yang cukup tinggi, misalnya pada aset-aset finansial seperti saham, warrants, options, serta futures baik di pasar modal domestik maupun di pasar modal internasional. Alternatif investasi yang menjanjikan pendapatan tinggi dengan risiko yang tinggi adalah investasi dalam bentuk saham.

Investor yang cerdas dalam melakukan kegiatan investasi, akan memilih bentuk investasi saham yang mampu menawarkan tingkat pendapatan yang diharapan paling tinggi dengan tingkat risiko tertentu, atau investasi saham yang menawarkan return tertentu dengan tingkat risiko terendah. Hal ini disebabkan, imbal hasil dari investasi saham yang diperoleh investor di masa datang mencerminkan harapan yang belum tentu terealisasi atau tidak pasti, sehingga mengakibatkan investor menanggung suatu risiko dari investasi saham yang dilakukan.

Salah satu cara yang dapat dilakukan investor untuk mengurangi risiko investasi saham adalah dengan jalan melakukan diversifikasi investasi dalam bentuk portofolio investasi saham. Diversifikasi investasi dapat dilakukan dengan memilih berbagai saham dari perusahaan atau industri yang berbeda dalam satu negara (diversifikasi domestik) atau memilih saham dari berbagai perusahaan atau industri dari beberapa negara yang berbeda-beda (diversifikasi internasional). Pemilihan berbagai saham dari perusahaan yang berbeda pada diversifikasi investasi, sesuai dengan pertimbangan yang berdasarkan hasil empiris sebagaimana yang dikemukakan oleh Sudana dan Janiarti, (2000), bahwa pembentukan suatu portfolio melalui diversifikasi saham beragam industri menghasilkan risiko yang lebih kecil daripada penyusunan portofolio melalui diversifikasi saham satu industri. 
Diversifikasi investasi dikembangkan atas dasar hukum "large number", yang menyatakan, jika menambahkan secara terus menerus berbagai jenis saham ke dalam portofolio, maka manfaat pengurangan risiko yang diperoleh akan semakin besar, sampai mencapai titik tertentu apabila portofolio ditambah dengan satu saham atau lebih, tidak akan terjadi penurunan risiko yang berarti. Hal ini menunjukkan bahwa komposisi jumlah saham penyusun portofolio tersebut telah mencapai optimal. Pernyataan tersebut sesuai dengan hasil penelitian yang dilakukan oleh Suqaier \& Ziyud, (2011) serta Ahuja (2011). Kedua penelitian ini menyatakan bahwa penambahan saham yang semakin banyak ke dalam portofolio dapat menurunkan risiko sampai dengan titik tertentu, jika portofolio tersebut ditambahkan dengan saham lagi, tidak diperoleh penurunan risiko yang berarti, karena jumlah saham yang menyusun portofolio telah mencapai optimal. Jumlah saham optimal untuk membentuk suatu portofolio, didapatkan oleh Suqaier \& Ziyud, (2011) sebanyak 15-16 saham, untuk penelitian yang dilakukan oleh Ahuja, (2011) diperoleh jumlah saham optimal sebanyak 10 saham.

Investasi saham di pasar modal Indonesia dari tahun ke tahun menunjukkan perkembangan. Hal ini dapat dilihat dari peningkatan indeks harga saham unggulan, yaitu indeks LQ45. Pergerakan indeks LQ45 mengalami peningkatan, dari 667,95 pada awal Januari 2011 menjadi 680 pada akhir Desember 2011. Hal tersebut mengindikasikan bahwa banyak investor yang tertarik menanamkan modalnya dalam investasi saham yang tergolong bluechip di Bursa Efek Indonesia.

Bentuk diversifikasi investasi saham di pasar modal Indonesia salah satunya ditunjukkan oleh perkembangan investasi dalam bentuk reksadana saham. Reksadana saham merupakan diversifikasi investasi yang terdiri dari saham-saham dari berbagai perusahaan atau industri yang berbeda yang dilakukan oleh manajer investasi. Perkembangan investasi dalam bentuk reksadana telah meningkat, dari Rp. 60,4 triliun pada awal Januari 2011 menjadi Rp. 62,2 triliun di penghujung bulan Desember 2011. Investor dalam investasi saham dapat pula melakukan diversifikasi sendiri secara aktif. Hal ini tentu memerlukan jumlah dana yang jauh lebih besar dibandingkan dengan berinvestasi dalam bentuk reksadana yang telah terdiversifikasi.

Di sisi lain, kondisi investasi saham di berbagai negara seperti USA, Jerman dan Inggris menunjukkan perkembangan yang berbeda-beda. Perkembangan investasi saham pada awal Januari 2011 sampai dengan akhir Desember 2011 di USA, berdasarkan pergerakan indeks DJIA menunjukkan peningkatan dari 11.670,75 menjadi 12.217,56. Kondisi sebaliknya terjadi di Jerman pergerakan indeks DAX30 mengalami penurunan dari 6.989,74 pada awal Januari 2011 menjadi 5.898,35 pada akhir Desember 2011, demikian juga di Inggris, berdasarkan pergerakan indeks FTSE100 mengalami penurunan dari 6.013,9 pada awal Januari 2011 menjadi 5.572,3 pada akhir Desember 2011.

Perkembangan investasi dalam bentuk portofolio yang telah terdiversifikasi dalam bentuk mutual fund internasional, yaitu portofolio yang terdiri dari berbagai saham perusahaan di berbagai negara menunjukkan penurunan, yakni awal Januari 2011 , jumlah total dana yang dikelola sebanyak $\$ 5,584.69$ milyar menjadi sebesar $\$ 5,205.11$ milyar. Penurunan investasi yang terjadi pada mutual fund internasional, disebabkan adanya ketidakpercayaan investor untuk menanamkan modalnya pada berbagai saham perusahaan di berbagai negara Eropa dan USA. Ketidakpercayaan investor tersebut dikarenakan dalam rentang waktu awal Januari hingga akhir Desember di tahun 2011, kondisi ekonomi di negara tersebut yang belum sepenuhnya pulih dari pengaruh krisis ekonomi global yang bermula dari USA hingga berimbas di negara-negara Eropa bagian barat, seperti di Inggris dan Jerman. Akibat dari krisis ekonomi global tersebut banyak sekali perusahaan yang tidak bisa menghindari kebangkrutan, terjadi peningkatan pengangguran, penurunan penawaran serta permintaan barang dan jasa sehingga efek domino dari krisis global tersebut membuat kerugian bagi investor. Penurunan investasi pada mutual fund internasional ini bertentangan 
dengan pernyataan Solnik, (1995) yang menyatakan bahwa investor lebih tertarik melakukan diversifikasi internasional, karena total risiko yang dihasilkan diversifikasi internasional lebih kecil daripada diversifikasi domestik.

Dengan adanya perkembangan reksadana saham domestik dan reksadana saham internasional yang berbeda, dan perkembangan bursa saham antara negara satu dengan lainnya tidak sama menunjukkan bahwa adanya peluang bagi investor untuk melakukan diversifikasi, baik di pasar modal domestik maupun internasional. Penelitian ini mencoba untuk mengkaji perbedaan hasil diversifikasi yang dilakukan di pasar modal domestik dengan diversifikasi yang dilakukan di pasar modal internasional.

Berdasarkan penjelasan dari latar nelakang tersebut, tujuan dari penelitian ini, yakni: untuk mengetahui perbedaan risiko diversifikasi investasi saham domestik dengan risiko diversifikasi saham internasional dan mengetahui pengaruh jumlah saham dalam portofolio terhadap total risiko portofolio.

\section{LANDASAN TEORI DAN PENGEMBANGAN HIPOTESIS}

\section{Penelitian Terdahulu}

Terdapat beberapa penelitian yang telah dilakukan sebelumnya berkaitan dengan diversifikasi investasi saham ditinjau dari berbagai sudut pandang, di antaranya adalah: Sudana \& Janiarti (2000) meneliti tentang ada atau tidaknya perbedaan risiko portofolio yang dihasilkan dari portofolio saham yang terdiri dari saham satu industri dengan portofolio saham yang terdiri dari berbagai industri. Variabel yang dipakai di dalam percobaan ini, ialah ukuran portofolio yang merupakan banyaknya jumlah saham dalam portofolio serta risiko total portofolio saham yang merupakan penjumlahan risiko tidak sistematis dengan risiko sistematis. Sampel yang digunakan di dalam penelitian ini, untuk portofolio saham satu industri merupakan perusahaan-perusahaan yang sahamnya tercatat di Bursa Efek Jakarta dalam kurun waktu antara tahun 1990-1996 yang terdiri dari saham-saham perusahaan tekstil serta produk tekstil (TPT), sedangkan untuk portofolio saham beragam industri terdiri dari saham-saham perusahaan dari beragam industri. Model analisis yang digunakan adalah uji perbandingan, uji † selisih dua rata-rata. Hasil penelitian menunjukkan rata-rata nilai risiko tidak sistematis portofolio saham satu industri untuk semua ukuran adalah lebih tinggi bila dibandingkan dengan rata-rata nilai risiko tidak sistematis portofolio saham beragam industri, dan secara statistik terdapat perbedaan yang signifikan;

Solnik (1995), melakukan penelitian tentang ada tidaknya perbedaan total risiko yang dihasilkan dari portofolio yang dibentuk melalui diversifikasi domestik dengan portofolio yang dibentuk melalui diversifikasi internasional. Percobaan yang dilakukan oleh Solnik, menggunakan variabel risiko total portofolio dan jumlah saham. Sampel yang digunakan dalam penelitian ini adalah 300 saham yang terdaftar di Bursa Efek Amerika Serikat serta total 300 saham yang terdaftar di 7 Negara Eropa, seperti Inggris, Jerman, Perancis, Swiss, Italia, Belgia dan Belanda. Hasil penelitian menunjukkan bahwa diversifikasi saham pada berbagai negara menghasilkan risiko total lebih kecil daripada diversifikasi saham dalam satu negara saja, pada semua ukuran portofolio;

Suqaier \& Ziyud serta Ahuja di tahun 2011, kedua penelitian ini sama-sama menggunakan variabel jumlah saham serta risiko total portofolio. Suqaier \& Ziyud, (2011) membahas mengenai pengaruh jumlah saham terhadap risiko total portofolio dan juga menjelaskan tentang jumlah saham optimal untuk membentuk suatu portofolio. Sampel yang digunakan sebanyak 100 perusahaan terdaftar di Bursa Efek Amman, Yordania dengan rentang periode 6 tahun, yaitu dari periode 2 Desember 2005 sampai dengan 13 Maret 2010. Hasil penelitian menunjukkan dengan melakukan penambahan jumlah saham pada portofolio, maka risiko total portofolio mengalami penurunan, sampai dengan jumlah saham 15-16, dan jika ditambahkan satu atau lebih saham lagi maka tidak terjadi penurunan risiko portofolio 


\section{Tyas Aurumaa S.}

I Made Sudana

yang berarti; Penelitian Ahuja, (2011) melakukan eksperimen tentang analisis jumlah saham optimal yang menyusun portofolio. Data yang digunakan merupakan harga saham penutup harian periode 2007 sampai dengan 2009. Saham-saham yang digunakan untuk membentuk suatu portofolio terpilih secara random, sebanyak 15 saham. Hasil penelitian menunjukkan bahwa dengan melakukan diversifikasi melalui penambahan jumlah saham dalam suatu portofolio, risiko portofolio yang dihasilkan semakin kecil. Jumlah saham optimal penyusun sebuah portofolio di dalam percobaan ini terdiri dari 10 saham.

\section{Investasi Saham}

Investasi dapat diartikan sebagai suatu kegiatan menempatkan dana pada satu atau lebih aset selama periode tertentu dengan harapan dapat memperoleh return atau meningkatkan nilai investasi. Dalam melakukan investasi, investor perlu memperkirakan pendapatan yang diharapkan atas investasinya untuk suatu periode tertentu di masa yang akan datang karena pendapatan saham bersifat tidak pasti atau berisiko.

Pasar modal dapat dilihat sebagai wahana serta alternatif dalam berinvestasi. Semakin maju dan berkembangnya suatu peradaban masyarakat, maka alternatif investasinya semakin banyak. Secara garis besar, ada dua alternatif investasi, yaitu investasi pada aset riil seperti emas, perak, permata, tanah, bangunan, mesin dan investasi pada aset finansial seperti saham dan obligasi. Investasi pada aset finansial dapat dilakukan di pasar modal, karena pasar modal menawarkan jenis efek keuangan jangka panjang yang dapat diperjualbelikan, baik dalam bentuk utang maupun modal sendiri, yang diterbitkan pemerintah, public authorities, maupun perusahaan swasta, hal ini memberikan peluang bagi investor untuk melakukan difersifikasi investasi.

\section{Difersifikasi}

Diversifikasi memiliki makna yang berbeda dengan portofolio. Diversifikasi adalah proses pembentukan investasi portofolio, melalui pemilihan kombinasi sejumlah aset sedemikian rupa sehingga risiko dapat diminimalkan. Cara melakukan diversifikasi adalah menyusun isi portofolio dengan instrumen kevangan seperti saham, obligasi, dan lain-lain, yang hasilnya disebut dengan portofolio.

Diversifikasi juga dapat dilakukan dengan menggunakan saham berbagai perusahaan, sehingga portofolio yang dibentuk terdiri dari satu jenis instrumen keuangan saja, yaitu saham. Terdapat 2 metode diversifikasi, yaitu diversifikasi Markowitz dan diversifikasi random.Diversifikasi random merupakan metode pembentukan suatu portofolio melalui pemilihan kombinasi satu jenis atau berbagai jenis instrumen keuangan secara acak tanpa memerhatikan karakteristik serta korelasi antar-instrumen keuangan yang digunakan. Diversifikasi dengan cara random berasumsi bahwa semakin banyak instrumen keuangan yang ditambahkan ke dalam portofolio, maka semakin besar penurunan risiko yang akan diperoleh, sampai pada akhirnya ketika dilakukan penambahan jumlah saham tertentu ke dalam portofolio tidak terjadi penurunan risiko yang berarti (Tandelilin, 2010:115-116).

Gambaran secara grafik mengenai penurunan risiko portofolio melalui diversifkasi dapat dilihat pada Grafik 1: 


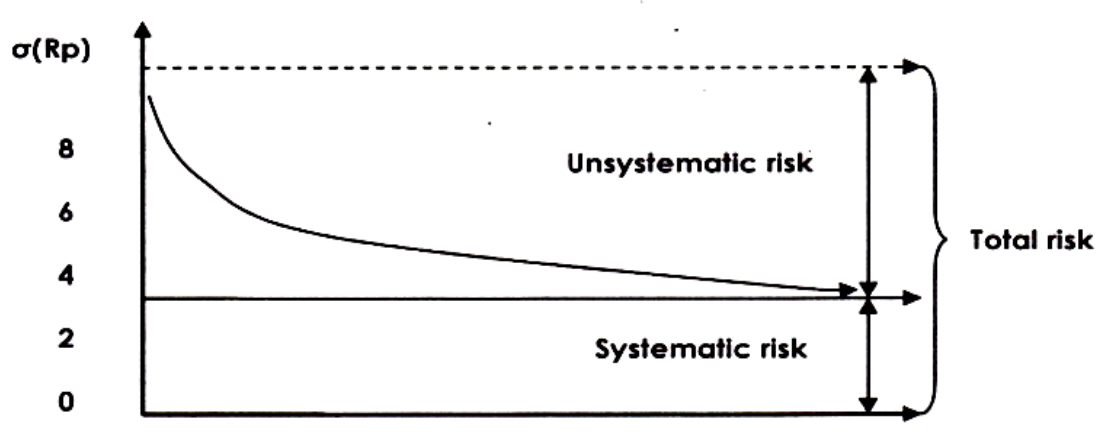

1, April 2013

1234567891011 Number of securities in the portfolio

Grafik 1: Pengurangan risiko melalui diversifikasi

Pada Grafik 1, tampak bahwa risiko total portofolio dibagi menjadi dua, yaitu risiko tidak sistematis dan risiko sistematis. Risiko tidak sistematis adalah bagian dari risiko total yang dapat dikurangi dengan jalan diversifikasi. Risiko ini timbul karena faktor-faktor internal perusahaan atau industri yang bersifat khas dan hanya berpengaruh terhadap perusahaan atau industri tertentu, misalnya faktor manajemen, struktur modal perusahaan, jenis produk dan teknologi yang digunakan. Risiko sistematis merupakan bagian dari risiko total yang tidak dapat dikurangi dengan diversifikasi. Risiko ini timbul karena faktor-faktor eksternal perusahaan dan berpengaruh terhadap semua perusahaan, misalnya kondisi ekonomi, politik, keamanan, dan sosial pada umumnya (Sudana, 2009:59).

Diversifikasi investasi internasional, merupakan suatu proses investasi yang berkaitan dengan bagaimana seorang investor membuat keputusan berinvestasi pada beberapa jenis aset di berbagai negara, kapan investasi seharusnya dilaksanakan dan di mana investasi dilakukan. Sudah terbukti secara empiris bahwa pembentukan portofolio melalui diversifikasi internasional memberikan manfaat lebih besar daripada hanya melakukan diversifikasi secara domestik. Dengan melakukan diversifikasi internasional, investor dapat menurunkan total risiko lebih besar bila dibandingkan dengan diversifikasi secara domestic. Hal ini disebabkan, dalam diversifikasi investasi saham secara internasional, investor tidak hanya mendiversifikasikan investasinya pada aset yang berbeda, tetapi juga mendiversifikasikan pada negara yang berbeda. Sesuai dengan konsep portofolio, diversifikasi pada berbagai aset dan berbagai negara mampu memberikan tingkat pendapatan yang diharapkan serta manfaat pengurangan risiko yang lebih besar dibandingkan dengan berinvestasi hanya pada pasar modal domestik saja (Tandelilin, 2010:505). Keuntungan investor yang melakukan diversifikasi secara internasional, diperoleh kesempatan berinvestasi pada jumlah serta jenis aset yang berbeda dengan korelasi yang relatif rendah. Keuntungan tersebut tidak dapat diperoleh pada diversifikasi domestik sebab diversifikasi domestik hanya dibatasi dengan korelasi antar aset domestik saja.

Dengan diverisifikasi internasional, dapat menurunkan dampak risiko nilai tukar mata uang (Madura,2010:85-87). Walaupun keuntungan diversifikasi internasional lebih besar daripada sisi kerugiannya, bagaimanapun sebagai seorang investor harus tetap mempelajari dan mengetahui kerugian yang melekat pada diversifikasi internasional. Kerugian diversifikasi internasional ialah adanya peningkatan korelasi pasar modal di berbagai negara seperti negara-negara yang ada di Eropa, terutama pada negara yang sama-sama menggunakan mata uang Euro. Peningkatan korelasi antar negara tersebut merupakan akibat dari integrasi antar pasar modal di berbagai negara di Eropa. Dengan adanya korelasi yang besar membawa dampak risiko yang besar pula, karena apabila terjadi krisis di salah satu pasar modal di suatu negara, maka pasar modal negara lain juga ikut terpengaruh adanya krisis tersebut.

\section{Metode diversifikasi}

Diversifikasi yang dilakukan melalui metode random untuk membentuk suatu portofolio, secara umum dapat dibedakan menjadi: simple random sampling, stratified random 


\section{Tyas Aurumaa S.}

I Made Sudana

sampling dan cluster random sampling (Nazir, 2009:325). Dalam penelitian ini, metode yang digunakan adalah stratified random sampling. Stratified random sampling merupakan suatu metode sampling atau pemilihan sampel yang dilakukan dengan cara menarik dengan memisahkan elemen-elemen populasi dalam kelompok-kelompok yang tidak overlapping yang disebut strata, dan kemudian memilih sebuah sampel secara random dari tiap stratum. Penggunaan stratified random sampling tersebut memiliki tujuan supaya sampel yang akan diteliti lebih representatif, sehingga perlu membagi kelas-kelas atau subpopulasi dari total populasi secara keseluruhan. Pembagian tersebut dilakukan untuk memberikan homogenitas yang lebih nyata di dalam masing-masing subpopulasi dan memberikan heterogenitas yang nyata antar subpopulasi (Nazir,2009:31 1-315).

Hasil dari proses diversifikasi adalah portofolio. Permasalahan berikutnya adalah bagaimana cara mengukur risiko dan pendapatan portofolio.

\section{Pendapatan dan Risiko Portofolio}

Pengukuran pendapatan dan risiko portofolio harus dimulai dari pengukuran pendapatan dan risiko investasi saham individual.Pendapatan saham merupakan hasil yang diperoleh dari investasi saham. Pendapatan investasi saham dibedakan menjadi: pendapatan aktual (yang sudah terjadi) dan pendapatan ekspektasi (belum terjadi, tetapi diharapkan terjadi pada masa yang akan datang). Pendapatan aktual yang diterima oleh investor dari investasi saham dalam periode tertentu, dapat berupa capital gain dan atau dividen. Perhitungan pendapatan aktual, didasarkan pada data historis. Pendapatan aktual juga dapat digunakan sebagai dasar penentuan pendapatan yang diharapkan dan risiko pada masa yang akan datang. Oleh karena investasi portofolio terdiri dari banyak saham, untuk mengukur besar kecilnya pendapatan portofolio yang diterima oleh investor, terlebih dahulu harus menghitung pendapatan aktual dari masing-masing saham berupa capital gain saja atau capital gain dan dividen. Perhitungan pendapatan aktual investasi saham berupa capital gain, diukur dengan cara:

$$
R_{i, t}=\frac{P_{i, t}-P_{i, t-1}}{P_{i, t}, 1}
$$

Keterangan:

$R_{i, t}=$ pendapatan aktual saham i pada waktu $\dagger$

$P_{i, t}=$ harga saham $i$ penutup pada waktu $t$

$P_{i, t}=$ harga saham $i$ penutup pada waktu $t-1$

Pendapatan yang diharapkan dari investasi saham dapat diukur dengan rumus sebagai berikut:

$$
\overline{R i}=\frac{\sum R i t}{T} .
$$

Sulistiono, (2006) mengemukakan, dalam melakukan investasi saham, investor sebaiknya tidak hanya mempertimbangkan besarnya pendapatan yang akan diperoleh, tetapi juga perlu memperhatikan variabilitas pendapatan saham tersebut dari waktu ke waktu. Variabilitas pendapatan saham inilah yang disebut dengan risiko investasi saham. Risiko juga dapat diartikan sebagai kemungkinan bahwa kejadian aktual dari keputusan investasi berbeda dengan yang diharapkan. Dalam setiap pengambilan keputusan investasi, risiko merupakan faktor yang penting untuk dipertimbangkan, karena besar kecilnya risiko yang terkandung dalam suatu alternatif investasi akan memengaruhi pendapatan yang diharapkan dari investasi tersebut. Apabila risiko investasi saham semakin tinggi, sementara pendapatan saham tetap, maka nilai saham akan semakin rendah sehingga dapat mengakibatkan harga saham turun dan sebaliknya.

Pendapatan serta risiko merupakan suatu trade-off, dan keduanya memiliki hubungan yang positif. Semakin besar risiko yang ditanggung, maka semakin besar pula pendapatan yang 
diharapkan sebagai kompensasi risiko. Pengukuran risiko total suatu investasi tunggal, yakni saham dapat dilakukan dengan menghitung varians atau deviasi standar pendapatan saham, yang mengukur penyimpangan nilai-nilai pendapatan yang sudah terjadi dengan pendapatan yang diharapkan. Semakin tinggi deviasi standar, maka semakin tinggi risiko investasi saham suatu perusahaan, sebaliknya deviasi standar yang rendah menunjukkan risiko investasi saham yang rendah pula. Besar kecilnya risiko saham individu diukur dengan varians, atau standar deviasi sebagai berikut:

$$
\sigma_{R_{1}}^{2}=\frac{\sum_{t=1}^{n}\left(R_{i, t}-\bar{R}_{i}\right)^{2}}{n-1}
$$

Keterangan:

$\sigma_{R_{\mathrm{i}}}^{2}=$ varians pendapatan saham i

$\bar{R}_{i}=$ pendapatan yang diharapkan untuk saham $i$

$R_{i, t}=$ pendapatan aktual saham $i$

$n$ = jumlah holding period dari saham $i$

Untuk menghitung risiko saham dengan deviasi standar, menggunakan rumus:

$$
\sigma_{R_{\mathrm{i}}}=\sqrt{\sigma_{R_{\mathrm{i}}}^{2}}
$$

Keterangan:

$\sigma_{R_{\mathrm{i}}}=$ standar deviasi pendapatan saham $i$

Risiko portofolio ditentukan oleh tiga faktor, yaitu risiko masing-masing saham yang membentuk portofolio, proporsi dana yang diinvestasikan pada masing-masing saham, dan korelasi pendapatan antara saham dalam portofolio. Sofiana \& Widodo, (2008) mengemukakan bahwa, konsep risiko portofolio tersebut dapat diestimasi dengan cara mengukur varian portofolio tersebut, jika return saham yang ada dalam portofolio tidak saling memengaruhi satu dengan yang lainnya. Jadi, risiko portofolio bukan merupakan rata-rata tertimbang dari seluruh risiko sekuritas tunggal, tetapi risiko portofolio merupakan variabilitas pendapatan sekuritas-sekuritas yang membentuk portofolio tersebut, sehingga menghasilkan risiko yang lebih kecil dari risiko rata-rata tertimbang masing-masing sekuritas tunggal. Cara menghitung risiko portofolio, dalam hal ini merupakan portofolio saham, dengan cara:

$$
\sigma_{p}^{2}=\sum_{i=1}^{n} w_{i}^{2} \sigma_{i}^{2}+\sum_{i=1}^{n} \sum_{j=i+1, j \neq i}^{n} w_{i} w_{j} \operatorname{Cov}_{i j}
$$

Keterengan:

$\sigma_{p}^{2}=$ risiko total portofolio

$\sigma_{i}^{2}=$ varians pendapatan saham $i(i=1,2,3, \ldots \ldots \ldots$. , dan seterusnya $)$

$w_{i}=$ proporsi dana yang diinvestasikan dalam saham $i(i=1,2,3, \ldots \ldots . .$. dst $)$

$w_{j}=$ proporsi dana yang diinvestasikan dalam saham $j(j=2,3,4, \ldots \ldots \ldots$, dst $)$

$\operatorname{Cov}_{i j}=$ kovarian antara pendapatan saham $i$ dan $j$

(Zubir, 2011:43).

Jika, dimasukkan koefisien korelasi antara saham-saham dalam portofolio, maka risiko portofolio menjadi:

$$
\sigma_{p}^{2}=\sum_{i=1}^{n} w_{i}^{2} \sigma_{i}^{2}+\sum_{i=1}^{n} \sum_{j=i+1, j \neq i}^{n} w_{i} w_{j} \rho_{i j} \sigma_{i} \sigma_{j}
$$

Keterengan:

$\sigma_{p}^{2}=$ risiko total portofolio

$\sigma_{i}^{2}=$ varians pendapatan saham $i(i=1,2,3$, dan seterusnya)

$w_{i}=$ proporsi dana yang diinvestasikan dalam saham $i(i=1,2,3$,

$w_{j}=$ proporsi dana yang diinvestasikan dalam saham $j(j=2,3,4$, 
Tyas Aurumaa S.

I Made Sudana

$\rho_{i j}=$ korelasi antara pendapatan saham $i$ dan $j$

$\sigma_{i}=$ deviasi standar pendapatan saham $i(i=1,2,3, \ldots \ldots \ldots$. , dan seterusnya $)$

$\sigma_{j}=$ deviasi standar pendapatan saham $j(j=2,3,4, \ldots \ldots \ldots$. , dan seterusnya)

Jika, diasumsikan bahwa semua saham dalam portofolio tidak saling berkorelasi atau korelasi sama dengan nol, maka risiko portofolio menjadi:

$$
\sigma_{p}^{2}=\sum_{i=1}^{n} w_{i}^{2} \sigma_{i}^{2} \ldots \ldots \ldots \ldots \ldots \ldots(7)
$$

Keterengan:

$\sigma_{p}^{2}=$ risiko total portofolio

$\sigma_{i}^{2}=$ varians pendapatan saham $i(i=1,2,3, \ldots \ldots \ldots$. dan seterusnya)

$w_{i}=$ proporsi dana yang diinvestasikan dalam saham $i(i=1,2,3, \ldots \ldots . ., \mathrm{dst})$

(Zubir, 2011: 58).

Dalam kenyataannya, jarang sekali ditemukan koefisien korelasi antar saham sama dengan nol (tidak ada korelasi antar saham), umumnya antar saham memiliki korelasi antara +1 dan -1. Selain mempertimbangkan korelasi antar saham, dipertimbangkan juga proporsi investasi pada setiap saham dalam portofolio $(1 / n)$, maka risiko portofolio dapat diukur dengan cara:

$$
\begin{aligned}
& \sigma_{p}^{2}=\sum_{i=1}^{n}(1 / n)^{2} \sigma_{i}^{2}+\sum_{i=1}^{n} \sum_{j=i+1, j \neq i}^{n}(1 / n)(1 / n) \rho_{i j} \sigma_{i} \sigma_{j} . \\
& \sigma_{p}^{2}=\sum_{i=1}^{n}(1 / n)^{2} \sigma_{i}^{2}+\sum_{i=1}^{n} \sum_{j=i+1, j \neq i}^{n}(1 / n)^{2} \rho_{i j} \sigma_{i} \sigma_{j} .
\end{aligned}
$$

Keterengan:

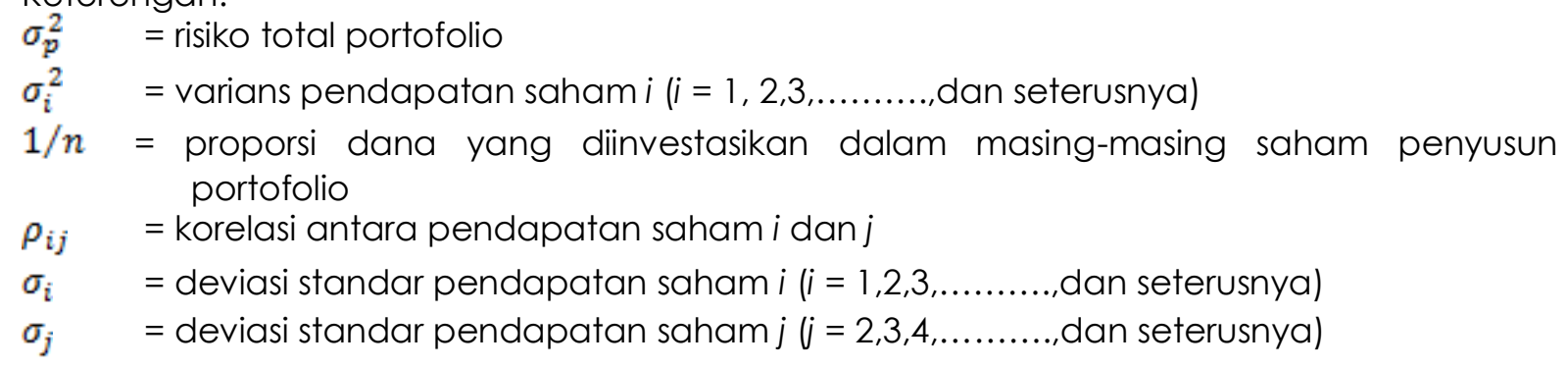

(Elton, Gruber, Brown \& Goetzmann, 2003: 58).

Dalam penelitian ini risiko total portofolio diukur dengan standar deviasi atau akar dari varians pendapatan portofolio, yang dihitung dengan rumus:

$$
\sigma_{p}=\sqrt{\sigma_{p}^{2}}
$$

\section{METODE PENELITIAN}

Populasi dalam penelitian ini adalah saham-saham perusahaan unggulan yang terdaftar dalam indeks saham DAX30 Jerman, indeks saham FTSE100 Inggris, indeks saham DJIA USA dan indeks saham LQ45 Indonesia. Metode pengambilan sampel adalah purposive sampling, yaitu pengambilan sampel berdasarkan kriteria tertentu, yaitu saham-saham perusahaan yang memiliki harga saham penutup harian secara konsisten dari awal Januari 2011 hingga akhir Desember 2011.

Variabel penelitiannya adalah risiko total portofolio, dan jumlah saham yang membentuk portofolio.

1. Risiko total portofolio saham merupakan penyimpangan pendapatan aktual dengan pendapatan yang diharapkan oleh investor. Risiko total portofolio diukur dengan menggunakan varians persamaan (4). 
2. Jumlah saham yang membentuk portofolio ialah banyaknya saham yang digunakan untuk membentuk suatu portofolio.

Jenis data yang digunakan dalam penelitian ini adalah data sekunder, yang merupakan data yang diperoleh secara tidak langsung atau merupakan data keuangan yang telah dipublikasikan. Data yang dikumpulkan untuk penelitian ini terdiri atas: harga saham penutup harian dari 28 saham yang terdaftar dalam indeks DAX30 Jerman, 65 saham dalam indeks FTSE100 Inggris, 30 saham indeks DJIA USA dan 31 saham indeks LQ45 Indonesia selama periode awal Januari- akhir Desember tahun 2011. Prosedur pengumpulan data secara keseluruhan di dalam penelitian ini dilakukan dengan cara dokumentasi, yaitu melalui browsing serta download pada website www.finance.yahoo.com.

\section{Teknik Analiais}

\section{Perbandingan risiko total portofolio diversifikasi domistik dengan internasional}

Langkah-langkah untuk melakukan analisis perbandingan risiko portofolio diversifikasi investasi saham domestik dan diversifikasi investasi saham internasional, sebagai berikut:

1. Menentukan dan mengelompokkan saham-saham domestik dan saham-saham internasional yang memiliki harga saham penutup harian dari periode Januari-Desember 2011 secara konsisten.

2. Menghitung pendapatan harian setiap saham, dengan menggunakan persamaan (1).

3. Menghitung pendapatan yang diharapkan harian setiap saham, dengan menggunakan persamaan (2).

4. Menghitung risiko total (standar deviasi) setiap saham, dengan menggunakan persamaan (4).

5. Menyusun portofolio saham baik portofolio saham domestik maupun portofolio saham internasional dengan jumlah saham terdiri atas 2 sampai dengan 20 saham.

a. Penyusunan portofolio domestik dibentuk dari saham-saham yang terdaftar dalam masing-masing indeks LQ45, indeks DAX30, indeks FTSE100 serta indeks DJIA. Jadi, untuk portofolio domestik Indonesia dibentuk dari kombinasi saham-saham yang terdaftar dalam indeks LQ45; untuk pembentukan portofolio domestik di Jerman, yaitu kombinasi saham-saham yang terdaftar dalam indeks DAX30; pembentukan portofolio domestik di Inggris melalui kombinasi saham-saham yang terdaftar dalam indeks FTSE100, kemudian untuk pembentukan portofolio domestik di USA dilakukan dengan mengkombinasikan saham-saham yang terdaftar dalam indeks DJIA.

b. Untuk penyusunan portofolio internasional, hal pertama yang dilakukan ialah menggabungkan saham-saham yang terdaftar dalam indeks LQ45, indeks DAX30, indeks FTSE100 dan indeks DJIA secara keseluruhan. Lalu dilanjutkan pembentukan portofolio saham internasional dengan cara melakukan kombinasi saham-saham tersebut.

c. Dalam menyusun portofolio, dengan kriteria jumlah saham 2 sampai 20 saham melalui kombinasi, sehingga diperoleh jumlah kombinasi yang berbeda-beda berdasarkan jumlah saham dalam portofolio. Kombinasi untuk membentuk portofolio dilakukan dengan menggunakan software Combinations! V2.0.

6. Menghitung rata-rata risiko total portofolio saham domestik maupun portofolio saham internasional sesuai dengan jumlah saham yang menyusun portofolio.

7. Melakukan uji t beda rata-rata total risiko dua kelompok sampel independen, yatu ratarata risiko total portofolio domestik dengan portofolio internasional, dengan rumus:

$$
t=\frac{\overline{\sigma_{(p) D}^{2}}-\overline{\sigma_{(p) I}^{2}}}{\sigma_{R_{(p) I \& D}}}
$$

Keterangan:

$\dagger \quad=$ Nilai $\dagger$ hitung 
$\overline{\sigma_{(p) D}^{2}} \quad=$ rata-rata risiko total portofolio saham domestik

$\overline{\sigma_{(p) I}^{2}} \quad=$ rata-rata risiko total portofolio saham internasional

$\sigma_{R_{(p) I \& D}}=$ standar deviasi risiko antar portofolio saham domestik dan portofolio saham internasional

Untuk menghitung nilai $\sigma_{R_{(p) I S D}}$, dapat dilakukan dengan rumus:

$$
\sigma_{R_{(p) I R D}}=\sqrt{\frac{\sigma_{R_{(p) I \& D}^{2}}^{2}+\frac{\sigma_{R_{(p) I R D}^{2}}^{2}}{n_{D}}}{n_{I}} .}
$$

Keterangan:

$\sigma_{R_{(p) I \Omega D}}=$ standar deviasi risiko antar portofolio saham domestik dan portofolio saham internasional

$\sigma_{R_{(p) i S D}}^{2}=$ varians total risiko dari portofolio saham domestik dan portofolio saham internasional

$n_{D} \quad=$ Jumlah kombinasi portofolio saham yang terbentuk melalui diversifikasi domestik

$n_{I} \quad=$ Jumlah kombinasi portofolio saham yang terbentuk melalui diversifikasi internasional

Untuk menghitung nilai $\sigma_{R_{(p) I \& D}}^{2}$ sendiri menggunakan formula sebagai berikut ini:

$$
\sigma_{R_{(p) I \& D}}^{2}=\frac{\left(n_{D}-1\right) \sigma_{R_{(p) D}^{2}}^{2}+\left(n_{I}-1\right) \sigma_{R_{(p) I}^{2}}^{2}}{\left(n_{D}-1\right)+\left(n_{I}-1\right)} .
$$

Keterangan:

$\sigma_{R_{(p) I S D}}^{2}=$ varians total risiko dari portofolio saham domestik dan portofolio saham internasional

$n_{D} \quad=$ Jumlah kombinasi portofolio saham yang terbentuk melalui diversifikasi domestik

$n_{I} \quad=$ Jumlah kombinasi portofolio saham yang terbentuk melalui diversifikasi internasional

$\sigma_{R_{(p) D}}^{2}=$ varians total risiko portofolio saham domestik

$\sigma_{R_{(p) I}}^{2}=$ varians total risikoportofolio saham internasional

\section{Pengaruh jumlah saham terhadap risiko total portofolio}

Untuk mengetahui pengaruh jumlah saham dalam portofolio terhadap risiko total portofolio dilakukan analisis regresi sederhana, dengan langkah-langkah sebagai berikut:

1. Melakukan langkah 1 sampai langkah 6, seperti pada teknik analisis permasalahan pertama.

2. Melakukan analisis regresi, melalui persamaan regresi seperti pada persamaan

$$
\sigma_{(p)}=A+\beta\left(\frac{1}{n_{i}}\right)+\varepsilon_{i}
$$

Keterangan:

$\sigma_{(p)}=$ risiko total portofolio berdasarkan jumlah saham yang membentuk

$n_{i}=$ jumlah saham penyusun portofolio $(i=2,3,4$ 20 saham)

$A=$ konstanta

$\beta=$ koefisien regresi yang megukur pengaruh jumlah saham terhadap risiko total portofolio

$\varepsilon_{i}=$ error (Suqaier \& Ziyud, 2011:61). 
3. Melakukan uji † untuk menentukan signifikansi pengaruh jumlah saham dalam portofolio terhadap risiko total portofolio.

\section{HASIL DAN PEMBAHASAN}

\section{Deskripsi Variabel Penelitian}

Obyek penelitian ini adalah saham-saham unggulan yang terdaftar dalam indeks LQ45 (Indonesia), indeks DAX30 (Jerman), indeks FTSE100 (Inggris) dan indeks DJIA (USA) yang mencantumkan harga saham penutup secara berturut-turut dalam jangka waktu awal Januari 2011 hingga akhir Desember 2011.

Sebelum melakukan pembentukan portofolio, dilakukan pemilihan saham terlebih dahulu, dengan cara random dari masing-masing indeks saham untuk membentuk portofolio saham domestik, sedangkan untuk membentuk portofolio saham internasional dilakukan pemilihan saham secara random dari campuran keempat indeks, yaitu indeks LQ45, indeks DAX30, indeks FTSE100 serta indeks DJIA.

Pemilihan saham yang dilakukan secara random baik untuk portofolio saham domistik maupun portofolio saham internasional, yaitu portofolio Indonesia, portofolio Inggris, portofolio Jerman dan portofolio USA, hanya dibatasi memilih serta melakukan kombinasi sampai dengan 20 saham saja. Hal ini didasarkan pada pertimbangan hasil penelitian sebelumnya, yang menunjukkan bahwa penurunan risiko portofolio sudah tidak berarti lagi ketika jumlah saham mencapai 15 sampai dengan 16 saham.

Dari saham-saham yang dipilih kemudian dibentuk portofolio secara random, yang terdiri dari 2 saham sampai dengan 20 saham, baik untuk portofolio domestik maupun portofolio internasional. Masing-masing kombinasi portofolio kemudian diukur risiko totalnya dengan standar devias.i

Adapun rata-rata standar deviasi (rata-rata risiko total) masing-masing portofolio tampak pada Tabel 1, berikut ini: 
Tyas Aurumaa S.

I Made Sudana

Tabel 1 Deskripsi Risiko Portofolio Diversifikasi Domestik Indonesia, Jerman, Inggris, USA dan Diversifikasi Internasional

\begin{tabular}{|c|c|c|c|c|c|c|}
\hline \multirow{2}{*}{$\begin{array}{c}\text { Jumlah } \\
\text { Saham }\end{array}$} & $\begin{array}{c}\text { Jumlah } \\
\text { Kombinasi } \\
\text { Portofolio }\end{array}$ & \multicolumn{5}{|c|}{ Mean Standar Deviasi Portofolio } \\
\cline { 3 - 7 } & 210 & 0,01995 & 0,02743 & 0,02524 & 0,02171 & 0,02349 \\
\hline 2 & 1330 & 0,01689 & 0,02432 & 0,02225 & 0,01895 & 0,02055 \\
\hline 3 & 5985 & 0,01555 & 0,02262 & 0,02068 & 0,01742 & 0,01913 \\
\hline 5 & 20349 & 0,01514 & 0,02217 & 0,02028 & 0,01704 & 0,01878 \\
\hline 6 & 54264 & 0,01487 & 0,02194 & 0,02010 & 0,01690 & 0,01861 \\
\hline 7 & 116280 & 0,01477 & 0,02183 & 0,02000 & 0,01679 & 0,01843 \\
\hline 8 & 203490 & 0,01467 & 0,02175 & 0,01999 & 0,01676 & 0,01835 \\
\hline 9 & 293930 & 0,01459 & 0,02168 & 0,01988 & 0,01673 & 0,01832 \\
\hline 10 & 352716 & 0,01450 & 0,02164 & 0,01986 & 0,01669 & 0,01829 \\
\hline 11 & 352716 & 0,01449 & 0,02158 & 0,01982 & 0,01665 & 0,01825 \\
\hline 12 & 293930 & 0,01442 & 0,02147 & 0,01979 & 0,01664 & 0,01825 \\
\hline 13 & 203490 & 0,01438 & 0,02145 & 0,01976 & 0,01661 & 0,01822 \\
\hline 14 & 116280 & 0,01435 & 0,02138 & 0,01970 & 0,01658 & 0,01818 \\
\hline 15 & 54264 & 0,01428 & 0,02135 & 0,01967 & 0,01655 & 0,01816 \\
\hline 16 & 20349 & 0,01427 & 0,02135 & 0,01967 & 0,01655 & 0,01816 \\
\hline 17 & 5985 & 0,01426 & 0,02135 & 0,01966 & 0,01655 & 0,01816 \\
\hline 18 & 1330 & 0,01426 & 0,02134 & 0,01966 & 0,01654 & 0,01815 \\
\hline 19 & 210 & 0,01426 & 0,02134 & 0,01965 & 0,01654 & 0,01815 \\
\hline 20 & 21 & 0,01425 & 0,02134 & 0,01965 & 0,01653 & 0,01814 \\
\hline
\end{tabular}

Sumber: data diolah

Berdasarkan Tabel 1, Penurunan nilai risiko total portofolio yang terjadi dalam diversifikasi internasional dari 0,01995 pada 2 saham menjadi 0,01425 pada 20 saham atau tingkat risiko total portofolio turun sebesar $28,6 \%$., sedangkan penurunan nilai risiko total portofolio melalui diversifikasi domestik Indonesia, dari 0,02743 pada 2 saham menjadi 0,02134 pada 20 saham atau tingkat risiko total portofolio turun sebesar 22,2\%, Jerman, dari 0,02524 pada 2 saham menjadi 0,01965 pada 20 saham atau tingkat risiko total portofolio turun sebesar $22,2 \%$, Inggris, dari 0,02171 pada 2 saham menjadi 0,01653 pada 20 saham atau tingkat risiko total portofolio turun sebesar $23,9 \%$., dan USA, dari 0,02349 pada 2 saham menjadi 0,01814 pada 20 saham atau tingkat risiko total portofolio turun sebesar $22,8 \%$.

Hal ini menunjukkan, diversifikasi internasional mampu menurunkan risiko total portofolio lebih besar dibandingkan dengan penurunan nilai risiko total portofolio yang dihasilkan melalui diversifikasi domestik. Selain itu, Tabel 5.1 juga memperlihatkan bahwa diversifikasi internasional memiliki nilai standar deviasi (risiko total) portofolio lebih rendah dibandingkan dengan diversifikasi domestik.

\section{Analisis Hasil Penelitian}

\section{Perbedaan Risiko Total Portofolio Internasional Dengan Domestik}

Untuk mengetahui ada atau tidaknya perbedaan risiko total portofolio yang dihasilkan dari diversifikasi saham secara internasional dengan diversifikasi saham secara domestik, 
dilakukan dengan menggunakan uji t beda dua rata-rata kelompok sampel independen, yang hasilnya secara ringkas dipaparkan pada Tabel 2, berikut ini:

Tabel 2 Hasil Uji † Beda Rata-rata Risiko Total Portofolio Diversifikasi Internasional dengan Diversifikasi Domestik

\begin{tabular}{|c|c|c|c|c|c|c|c|c|c|}
\hline \multirow{2}{*}{$\begin{array}{c}\text { Jumlah } \\
\text { Saham }\end{array}$} & $\begin{array}{c}\text { Jumlah } \\
\text { Kombinasi } \\
\text { Portofolio }\end{array}$ & \multicolumn{2}{|c|}{$\begin{array}{c}\text { Internasional vs } \\
\text { Indonesia }\end{array}$} & \multicolumn{2}{|c|}{$\begin{array}{c}\text { Internasional vs } \\
\text { Jerman }\end{array}$} & \multicolumn{2}{|c|}{$\begin{array}{c}\text { Internasional vs } \\
\text { Inggris }\end{array}$} & \multicolumn{2}{|c|}{$\begin{array}{c}\text { Internasional vs } \\
\text { USA }\end{array}$} \\
\hline 2 & 210 & $-10926,688$ & 0,000 & $-35515,46$ & 0,000 & $-9388,155$ & 0,000 & $-22857,1$ & 0,000 \\
\hline 3 & 1330 & $-18270,475$ & 0,000 & $-10972,18$ & 0,000 & $-4363,712$ & 0,000 & $-8649,76$ & 0,000 \\
\hline 4 & 5985 & $-1152,317$ & 0,000 & $-838,022$ & 0,000 & $-211,625$ & 0,000 & $-583,9$ & 0,000 \\
\hline 5 & 20349 & $-3050,747$ & 0,000 & $-2932,302$ & 0,000 & $-1024,350$ & 0,000 & $-2036,06$ & 0,000 \\
6 & 54264 & $-2199,151$ & 0,000 & $-1833,893$ & 0,000 & $-667,932$ & 0,000 & $-1280,93$ & 0,000 \\
\hline 7 & 116280 & $-1062,014$ & 0,000 & $-784,488$ & 0,000 & $-305,221$ & 0,000 & $-548,425$ & 0,000 \\
\hline 8 & 203490 & $-1283,433$ & 0,000 & $-953,629$ & 0,000 & $-353,918$ & 0,000 & $-643,347$ & 0,000 \\
\hline 9 & 293930 & $-1093,559$ & 0,000 & $-796,999$ & 0,000 & $-305,160$ & 0,000 & $-548,021$ & 0,000 \\
10 & 352716 & $-983,890$ & 0,000 & $-726,356$ & 0,000 & $-285,770$ & 0,000 & $-490,337$ & 0,000 \\
11 & 352716 & $-973,375$ & 0,000 & $-720,738$ & 0,000 & $-282,443$ & 0,000 & $-486,522$ & 0,000 \\
12 & 293930 & $-1029,797$ & 0,000 & $-791,385$ & 0,000 & $-312,730$ & 0,000 & $-552,486$ & 0,000 \\
13 & 203490 & $-918,121$ & 0,000 & $-748,394$ & 0,000 & $-312,196$ & 0,000 & $-466,888$ & 0,000 \\
14 & 116280 & $-802,284$ & 0,000 & $-614,094$ & 0,000 & $-270,281$ & 0,000 & $-354,541$ & 0,000 \\
15 & 54264 & $-1580,242$ & 0,000 & $-1198,618$ & 0,000 & $-495,235$ & 0,000 & $-347,675$ & 0,000 \\
16 & 20349 & $-1026,198$ & 0,000 & $-782,872$ & 0,000 & $-331,191$ & 0,000 & $-563,959$ & 0,000 \\
17 & 5985 & $-551,112$ & 0,000 & $-420,768$ & 0,000 & $-179,417$ & 0,000 & $-304,009$ & 0,000 \\
\hline 18 & 1330 & $-270,373$ & 0,000 & $-206,397$ & 0,000 & $-88,906$ & 0,000 & $-149,692$ & 0,000 \\
19 & 210 & $-37542,312$ & 0,000 & $-1771,108$ & 0,000 & $-10746,809$ & 0,000 & $-20299,3$ & 0,000 \\
\hline 20 & 21 & $-11081,486$ & 0,000 & $-8529,807$ & 0,000 & $-3597,868$ & 0,000 & $-6140,17$ & 0,000 \\
\hline
\end{tabular}

Sumber: data diolah

Berdasarkan Tabel 2 menunjukkan bahwa semua portofolio diversifikasi internasional memiliki risiko total portofolio yang lebih kecil dibandingkan dengan diversifikasi domestik yang ditunjukkan oleh nilai $\dagger$ hitung yang negatif. Berdasarkan hasil uji † menunjukkan terdapa perbedaan yang signifikan antara risiko portofolio yang dibentuk melalui diversifikasi internasional dibandingkan dengan risiko portofolio yang dibentuk melalui diversifikasi domestik pada $a=1 \%$.

\section{Pengaruh Jumlah Saham Terhadap Risiko Total Portofolio}

Permasalahan kedua, yaitu pengaruh jumlah saham terhadap risiko total portofolio diestimasi menggunakan persamaan regresi, dengan jumlah saham sebagai variabel bebas dan risiko total portofolio sebagai variabel terikat. Hasil regresi secara ringkas dipaparkan pada Tabel 3, sebagaimana berikut ini: 
Tabel 3 Hasil Analisis Regresi Pengaruh Jumlah Saham Terhadap Risiko Total Prtofolio Diversifikasi Domistik dan Internasional

\begin{tabular}{|c|c|c|c|c|}
\hline Model & Koefisien $\beta$ & Konstanta & Level of significant 19 & $\begin{array}{c}\text { Koefisen } \\
\text { Determinasi }\left(\mathrm{R}^{2}\right)\end{array}$ \\
\hline Internasional & $-1,7398 \mathrm{E}-04$ & 0,017 & 0,000 & 0,652 \\
\hline Indonesia & $-1,2807 \mathrm{E}-04$ & 0,024 & 0,000 & 0,540 \\
\hline Jerman & $-1,3778 \mathrm{E}-04$ & 0,022 & 0,000 & 0,553 \\
\hline Inggris & $-1,5200 \mathrm{E}-04$ & 0,019 & 0,000 & 0,585 \\
\hline USA & $-1,4387 \mathrm{E}-04$ & 0,020 & 0,000 & 0,569 \\
\hline
\end{tabular}

Sumber: data diolah

Tabel 3 menunjukkan bahwa jumlah saham dalam portofolio berpengaruh negatif terhadap risiko total portofolio pada semua bursa yang ditunjukkan oleh koefisien beta ( $\beta$ ). Hasil uji $\dagger$ statistik mengindikasikan bahwa jumlah saham dalam portofolio berpengaruh signifikan terhadap risiko total portofolio, baik untuk portofolio internasional maupun portofolio domestik pada level $1 \%$. Dengan kata lain, semakin banyak saham yang ditambahkan ke dalam portofolio, maka semakin kecil risiko total portofolio yang dihasilkan.

Nilai koefisien determinasi $\left(R^{2}\right)$ yang dihasilkan dari keseluruhan portofolio baik portofolio melalui diversifikasi internasional maupun portofolio melalui diversifikasi domestik berkisar antara 0,540 - 0,652. Hal ini menyatakan bahwa risiko total portofolio dari diversifikasi internasional maupun diversifikasi domestik pada semua bursa dipengaruhi oleh jumlah saham berkisar antara 54\% -65,2\% dan sisanya yang berkisar antara 34,8\% - 46\% dipengaruhi oleh faktor lain selain jumlah saham.

\section{Pembahasan}

\section{Perbedaan Risiko Total Portofolio Internasional Dengan Domestik}

Dari hasil analisis uji $t$ beda dua rata-rata kelompok sampel independen menunjukkan bahwa terdapat perbedaan yang signifikan antara risiko total portofolio yang dihasilkan melalui diversifikasi internasional dengan risiko total portofolio yang dihasilkan melalui diversifikasi domestik. Diversifikasi internasional menghasilkan risiko total portofolio lebih kecil daripada risiko total portofolio yang dihasilkan melalui diversifikasi domestik. Hasil penelitian ini sejalan dengan penelitian terdahulu yang dilakukan oleh Solnik, (1995).

Perbedaan risiko total portofolio yang dihasilkan melalui diversifikasi internasional dengan diversifikasi domestik, disebabkan portofolio yang dibentuk melalui diversifikasi internasional diversifikasinya tidak hanya antar saham tetapi juga antar negara. Kondisi bursa antar negara yang satu dengan negara lainnya sangat berbeda, sehingga bisa menurunkan risiko portofolio lebih besar dibandingkan dengan portofolio domestik yang portofolionya hanya berada dalam satu negara. Pada diversifikasi domestik, penurunan risiko terjadi karena adanya perbedaan saham saja, akibatnya penurunan risikonya lebih kecil daripada diversifikasi internasional. Perbedaan risiko total portofolio yang dihasilkan melalui diversifikasi internasional dan domestik dapat dilihat pada gambar 1 sebagaimana berikut ini: 
Gambar 1 Perbandingan Risiko Total Portofolio Melalui Diversifikasi Domestik dan Internasional

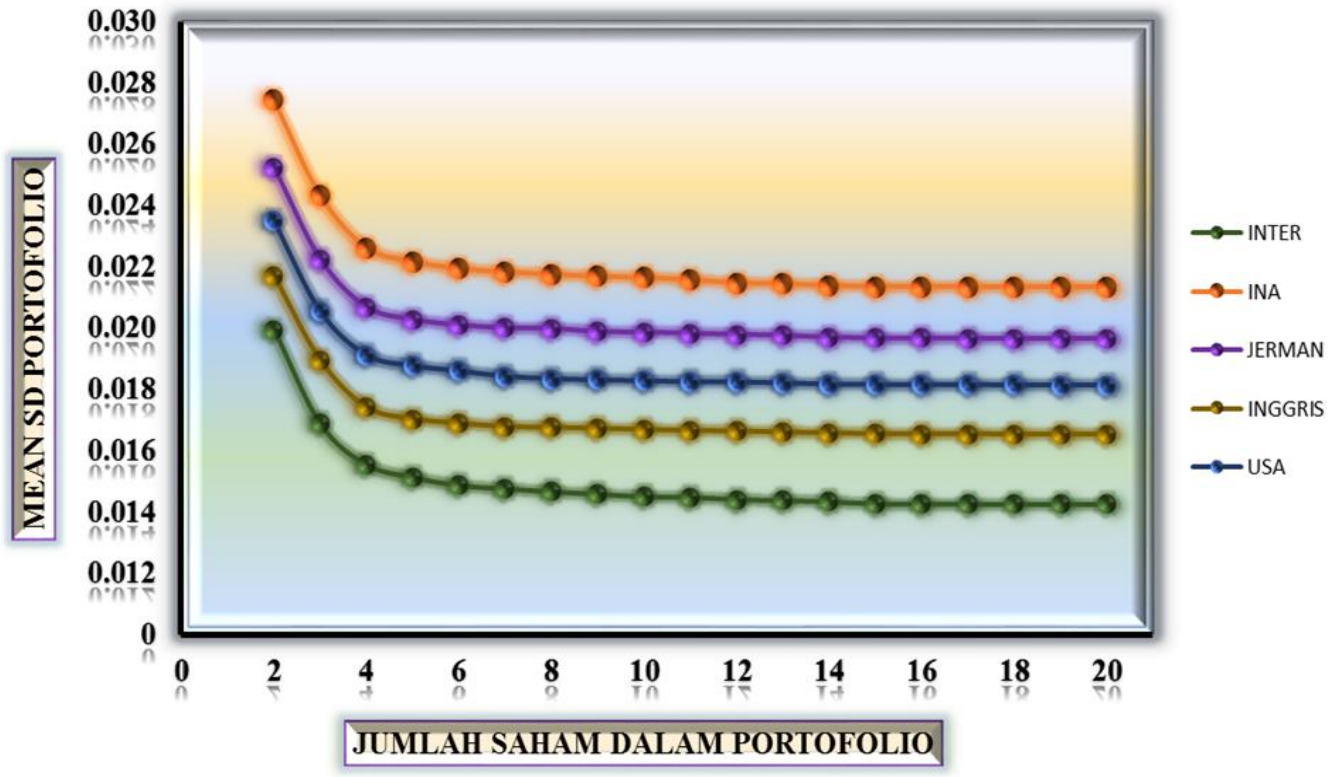

Gambar 1 memperlihatkan, risiko total portofolio yang dihasilkan dari keempat diversifikasi domestik menunjukkan tingkat yang berbeda-beda. Tingkat risiko total portofolio yang dihasilkan melalui diversifikasi domestik Indonesia paling tinggi di antara tingkat risiko total portofolio yang dihasilkan dari diversifikasi domestik Jerman, Inggris maupun USA, sedangkan diversifikasi domestik Inggris menghasilkan tingkat risiko total portofolio paling rendah. Penyebab diversifikasi domestik Indonesia menghasilkan tingkat risiko total portofolio paling tinggi dikarenakan banyaknya saham-saham yang masuk dalam LQ45 berasal dari satu industri yang sama, sedangkan pada diversifikasi domestik Inggris saham-saham yang masuk dalam FTSE100 berasal dari beragam industri. Dengan adanya saham-saham satu industry, hal tersebut dapat meningkatkan korelasi dalam pembentukan portofolio, yang berakibat pada risiko total portofolio di Indonesia lebih tinggi di Inggris. Hasil ini didukung hasil penelitian yang dilakukan sebelumnya oleh Sudana dan Janiarti, (2000). Risiko total portofolio diversifikasi internasional paling rendah dibandingkan dengan risiko total portofolio diversifikasi domistik, hal ini karena difersifikasinya tidak hanya antar saham tetapi juga antar Negara yang memeliki karakteristik yang berbeda-beda. Sementara untuk portofolio domistik diversifikasinya hanya terjadi antar saham. Kelemahan lain diversifikasi domestik, adalah apabila suatu negara yang mengalami krisis ekonomi, maka portofolio yang dibentuk, dari saham-saham domestik akan terpengaruh oleh kondisi krisis tersebut. Hal ini tidak terjadi pada diversifikasi internasional, sebab apabila ada salah satu negara yang mengalami krisis ekonomi, dan yang negara lain tidak, maka investor masih memperoleh keuntungan dari saham di negara yang tidak terjadi krisis, sehingga risiko total portofolionya menjadi lebih kecil dibandingkan portofolio hasil diversifikasi domestik.

\section{Pengaruh Jumlah Saham Terhadap Risiko Total Portofolio}

Berdasarkan hasil analisis pengaruh jumlah saham dalam portofolio menunjukkan bahwa jumlah saham dalam portofolio berpengaruh negatif signifikan terhadap risiko total portofolio. Artinya, semakin banyak jumlah saham dalam portofolio, maka semakin kecil risiko total portofolio, dan sebaliknya, semakin sedikit jumlah saham dalam portofolio, maka 
Tyas Aurumaa S.

I Made Sudana

semakin besar risiko total yang dihasilkan. Dengan kata lain, semakin banyak jumlah saham yang membentuk portofolio hasil diversifikasinya semakin baik, dalam hal ini risiko totalnya semakin kecil. Hal ini terjadi karena saham-saham yang membentuk portofolio memliki karakteristik yang berbeda-beda, sehingga menghasilkan diversifikasi yang semakin baik ( total risiko portofolio) semakin berkurang dengan dengan bertambahnya jumlah saham dalam portofolio.

\section{SIMPULAN}

Berdasarkan hasil serta analisis uji statistik, menyatakan bahwa:

1. Terdapat perbedaan antara risiko total portofolio yang dihasilkan melalui diversifikasi internasional dan diversifikasi domestik .

2. Risiko total portofolio yang dihasilkan melalui diversifikasi internasional lebih kecil daripada risiko total yang dihasilkan melalui diversifikasi domestik. Hal ini disebabkan dalam pembentukan portofolio melalui diversifikasi internasional tidak hanya melibatkan jenis saham yang berbeda, tetapi juga kondisi suatu negara yang berbeda.

3. Jumlah saham berpengaruh negatif signifikan terhadap risiko total portofolio,dengan kata lain, semakin banyak jumlah saham dalam suatu portofolio maka risiko total portofolionya semakin kecil.

\section{DAFTAR REFERENSI}

Ahuja. 2011 . Portfolio Diversification In The Karachi Stock Exchange. PJETS 1/1: 37-44.

Bodie, KM. 2009. Investment. $8^{\text {th }}$ edition. New York: The McGraw-Hill Companies, Inc.

Elton, Gruber, Brown, Goetzmann. 2009. Modern Portfolio Theory and Investment Analysis. $6^{\text {th }}$ edition. New York: John Wiley \& Sons, Inc.

Madura, J. 2010. International Corporate Finance. 10th edition. China: China Translation \& Printing Services Limited.

Nazir, M. 2009. Metode Penelitian. Cetakan Ketujuh. Bogor: Penerbit Ghalia Indonesia.

Sofiana \& Widodo. 2008. Penerapan Analisis Portofolio Saham Dalam Rangka Optimalisasi Return Dan Minimalisasi Risiko Pada Perusahaan Blue Chips. Jurnal Bisnis dan Manajemen 1/2: 104-118.

Solnik. 1995. Why Not Diversify Internationally Rather Than Domestically. Financial Analysts Journal (January-February 1995): 89-94.

Sudana \& Janiarti. 2000. Pengaruh Ukuran Portofolio Terhadap Tingkat Diversifikasi Saham: Perbandingan Antara Portofolio Saham Satu Industri Dengan Portofolio Saham Beragam Industri di Bursa Efek Jakarta. Majalah Ekonomi 10/1: 28-42

Sudana, IM. 2009. Manajemen Keuangan: Teori Dan Praktik. Cetakan Pertama. Surabaya: Airlangga University Press.

Sulistiono. 2006. Analisis Dan Desain Proses Pembentukan Portofolio Yang Optimal Perusahaan Yang Go Public Pada PT Bursa Efek Jakarta. SOSIAL, Jurnal IImu-IImu Sosial 2/1: 20-28.

Suqaier \& Ziyud. 2011. The Effect of Diversification on Achieving Optimal Portfolio. Eurojournals, Issue 32, ISSN 1450-2275.

Tandelilin. 2010. Portofolio dan Investasi: Teori dan Aplikasi. Edisi Pertama. Yogyakarta: Penerbit Kanisius.

www.finance.yahoo.com

Zubir, Z. 2011. Manajemen Portofolio: Penerapannya Dalam Investasi Saham. Jakarta: Penerbit Salemba Empat. 